\title{
A Case of Respiratory Distress in a Neonate
}

\author{
Lourdes Cohen* and Leanna Laor \\ Department of Pediatrics, Neonatal Division, Flushing Hospital Medical Center, USA
}

Submission: March 13, 2019; Published: April 12, 2019

*Corresponding author: Lourdes Cohen, Department of Pediatrics, Neonatal Division, Flushing Hospital Medical Center, 4500 Parsons Boulevard, Flushing, NY 11355, USA

Keywords: Respiratory distress; Newborn; Primary ciliary dyskinesia

\section{Introduction}

This case illustrates a rare cause of respiratory distress in a newborn who was found to be heterozygous for 2 variants on the Primary Ciliary Dyskinesia (PCD) gene, DNAH5, previously described as of unknown clinical significance.

\section{Case Presentation}

A female infant born to a 27-year-old via spontaneous vaginal delivery at 39 weeks' gestation; rupture of membranes was 8 hours prior to delivery, maternal hepatitis B surface antigen, HIV, RPR and Group B streptococcus were negative, and her amniotic fluid was clear. APGARs were 9,9 at 1 and 5 minutes respectively. No resuscitation at birth was required. Her prenatal course was unremarkable and there was no family history of chronic disease, congenital heart disease, or death in the neonatal period. Upon further questioning, parents were found to be consanguineous.

She was admitted to the well-baby nursery, and subsequently transferred to the Neonatal Intensive Care Unit (NICU) at 1 hour of life due to respiratory distress, which included tachypnea and desaturations, mild nasal flaring, no retractions or cyanosis were noted. On physical exam there were copious nasal secretions, the cardiac impulse was displaced to the right precordium, breath sounds were audible equally, and there were no rhonchi or rales. She had not dysmorphic features.

Differential diagnosis considers at the time of admission included aspiration of amniotic fluid, sepsis, congenital heart disease, pneumothorax, pneumonia, transient tachypnea of newborn, T-E fistula.

Imaging performed during admission, which included chest $\mathrm{x}$ ray, revealed dextrocardia and increase pulmonary markings, abdominal $\mathrm{x}$ ray and sonogram revealed situs inversus totalis, echocardiogram revealed mirror- image dextrocardia.

On admission to the NICU she was placed on nasal cannula and subsequently intubated due to respiratory failure. She was transitioned to nasal CPAP in 2 days and subsequently to nasal cannula. A full sepsis work-up was initiated, which included blood and CSF cultures and the patient was started on Ampicillin and Gentamicin. All cultures were negative, sepsis was ruled out and antibiotics were discontinued. Due to continued need of oxygen to maintain saturations in the low 90's, in the absence of air leaks, pneumonia or structural congenital heart disease and in the presence of dextrocardia with situs inversus totalis the diagnosis of ciliary dyskinesia was considered and a trial of Pulmozyme was given with subsequent improvement while awaiting for genetic testing results. She was discharged from the hospital on day 15 of life on Pulmozyme without need of oxygen supplementation. Her Auditory Brain Response (ABR) was normal.

Sequencing analysis of 11 PCD-related genes (DNAI 1, DNAI2, DNAH5, DNAH11, TXNDC3, RSPH4A, RSPH9, DNAAF1, DNAAF2, RPGR and OFD1), revealed heterozygosity for 2 variants: p.S906T and p.A369G in the DNAH5 gene, both variants were reported with unknown clinical significance. No mutations on the CFTR (cystic fibrosis transmembrane conductance regulator) gene was found.

On her follow up visits she continues to exhibit respiratory symptoms in the form of chronic cough, hyperactive airway disease, and poor weight gain. Nasal biopsy and electron microscopy of the nasal cilia was consistent with ciliary dyskinesia.

\section{Final Diagnosis}

DNAH5 gene mutation of unrecognized clinical significance associated with ciliary dyskinesia.

\section{Discussion}

Our case report identified a neonate who presented with severe respiratory distress in the neonatal period associated with situs inversus totalis. Genetic testing was negative for primary ciliary dyskinesia (PCD). However, the patient was found to be heterozygous for p.S906T and p.A369G, both variants of unknown significance on the DNAH5 gene. 
Situs inversus totalis is a rare condition where the normal positioning of the thoracic and abdominal organs is a mirror image of the normal anatomy. Prevalence of such a condition is estimated to be 1 in 10,000 [1]. Males and females are affected equally with an incidence of $1: 1$. The condition is generally diagnosed when the patient seeks medical attention due to an unrelated condition [2]. When the condition is associated with PCD, the patient is said to have Kartagener syndrome.

The DNAH5 (dynein axonemal heavy chain 5) is a gene that plays an integral part in the instructions for building the protein called dynein [3]. Dynein functions as the force to move cilia, the finger-like projections that are present on the cell surface allowing the cell or the fluid around it to move [3]. More than 80 mutations of the DNAH5 gene have been found to be associated with PCD, accounting for approximately $15 \%$ of all cases [4]. Other pathologies associated with mutations in DNAH5 include, sinusitis, bronchiectasis, chronic otitis media, and male infertility [4]. Generally speaking, in neonates with a diagnosis of PCD, more than $75 \%$ present with symptoms of respiratory distress, requiring supplemental oxygen for a period of time [5].

\section{Conclusion}

Our patient was found to be heterozygous for the p.S906T and p.A369G, both variants previously describe as of unknown clinical significance on the DNAH5 gene. We postulate that such a variant has clinical relevance since the baby presented in the neonatal period with significant respiratory distress requiring mechanical ventilation and oxygen supplementation, total situs inversus, chronic cough and failure to thieve.

\section{References}

1. Guido Oppido, Carlo Pace Napoleone, Stefania Martano, Gaetano Gargiulo (2004) Hypoplastic left heart syndrome in situs inversus totalis, European Journal of Cardio-Thoracic Surgery 26 (5): 1052-1054.

2. Uchenna DI, Jesuorobo DE, Anyalechi JI (2012) Dextrocardia with situs inversus totalis in an adult Nigerian: a case report. American Journal of Medicine and Medical Sciences 2(3): 59-61.

3. National Institute of Health (2018) DNAH5 gene.

4. Failly M, Bartoloni L, Letourneau A, Munoz A, Falconnet E, et al. (2009) Mutations in DNAH5 account for only 15\% of a non-preselected cohort of patients with primary ciliary dyskinesia. Journal of Medical Genetics 46(4): 281-286.

5. Zariwala MA, Knowles MR, Leigh MW (1993-2018) Primary Ciliary Dyskinesia. In: Adam MP, et al., (Eds) (2007) GeneReviews ${ }^{\circledR}$. Seattle (WA): University of Washington, USA.

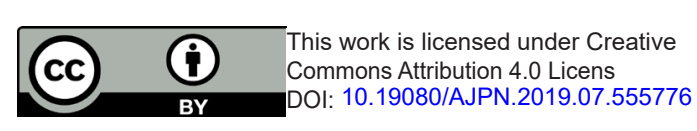

\section{Your next submission with Juniper Publishers will reach you the below assets}

- Quality Editorial service

- Swift Peer Review

- Reprints availability

- E-prints Service

- Manuscript Podcast for convenient understanding

- Global attainment for your research

- Manuscript accessibility in different formats

( Pdf, E-pub, Full Text, Audio)

- Unceasing customer service

Track the below URL for one-step submission https://juniperpublishers.com/online-submission.php 